\title{
Toxoplasma gondii INFECTION IN BRAZILIAN DOMESTIC OUTPATIENT CATS
}

\author{
Sílvia Regina Ricci LUCAS(1), Mitika Kuribayashi HAGIWARA(1), Valéria de Souza LOUREIRO(1), Júlia Yuzuki Habu IKESAKI(2) \& Eduardo Harry BIRGEL(1)
}

\begin{abstract}
SUMMARY
The occurrence of Toxoplasma antibodies in domestic outpatient cats in the city of São Paulo was evaluated using the indirect immunofluorescence assay.

A total of 248 blood samples obtained from male and female cats seen at the Veterinary Teaching Hospital at the University of São Paulo between February 1996 and January 1997 were tested. Of these, 17.7\% were positive, with a 64 titer being detected in most animals.

The frequence of Toxoplasma antibodies was significantly higher in older cats, those fed raw meat and those with free access to the outdoor environment. There was no significant difference in reactivity between males and females. We conclude that diet and free access to the outdoor environment were equally important as predisposing factors to the risk of Toxoplasma infection.
\end{abstract}

KEYWORDS: Toxoplasmosis; Feline toxoplasmosis; Cats

\section{INTRODUCTION}

Felids play a major role in the epidemiology of toxoplasmosis, since they are the definitive hosts of Toxoplasma gondii. Cats are also the only domestic animals in which the parasite completes the sexual stage of the life cycle, producing oocysts that are excreted in the feces and infect other hosts .

According to FRENKEL, $1973^{11}$ and AMATO et al., $1982^{1}$ toxoplasmosis is a major public health concern, because this zoonosis is an important cause of neonatal defects such as microcephaly, hydrocephaly, brain calcifications, and psychomotor and mental retardation. This makes the primary infection of pregnant women and, consequently, the transplacental infection of the fetus the most important aspect of human toxoplasmosis.

In general, indoor cats become infected by ingesting tissue cysts found in raw meat, while wild cats become infected after weaning, when they start hunting for small rodents and birds ${ }^{13}$.

After ingestion of tissue cysts or occasionally sporulated oocysts, the organism penetrates intestinal epithelial cells and disseminates throughout the body in blood and lymph. Both cats and intermediate hosts, including humans, develop the tissue phase of infection. Tissue cysts (with bradyzoites) develop as immune responses mature and persist for years after infection. They can be activated if immunodeficiency develops, and therefore special attention should be given to immunosuppressed patients with Acquired Immunodeficiency Syndrome (AIDS) ${ }^{12,16}$. These patients may develop toxoplasmic encephalitis, one of the major causes of death in AIDS patients ${ }^{17}$. The life cycle of $T$. gondii is completed when tissue cysts are ingested by cats. In the intestine, bradyzoites initiate an interepithelial cycle consisting of an asexual and a sexual cycle, resulting in fecal elimination of millions of oocysts for 1 to 3 weeks after primary exposure. Oocysts sporulate after 1 to 5 days and are infective to most vertebrates including humans ${ }^{7,14}$. Oocysts can survive for months to years under unfavorable environmental conditions and are remarkably resistant to most disinfectants ${ }^{6}$. Human beings and other animals become infected primarily by ingesting food or water ${ }^{3,7}$ contaminated with oocysts or by ingesting animal tissues that contain cysts of $T$. gondii ${ }^{7}$.

Toxoplasma gondii oocysts have been detected in the feces of $<1 \%$ of cats ${ }^{7}$. Because oocysts are small and the period of shedding is limited, the chance of detecting $T$. gondii oocysts is small ${ }^{7}$, so that epidemiological studies must be conducted using serologic tests. These studies have shown that the prevalence of Toxoplasma antibodies in the cat population is quite variable, from 0 to $100 \%$ depending on the method, number of animals studied and the geographic area $^{6}$. There are few reports regarding toxoplasmosis in cats in São Paulo. SOGORB et al. in 1972, found 45.0\% of positive cats using the Sabin-Feldman reaction test. LARSSON et al., in 1982, detected $40.8 \%$ of positive cats using the Sabin-Feldman reaction test and SANTOS et al., in 1983, analyzed 100 serum samples using the passive hemagglutination test and detected $59.0 \%$ of positives.

(1) Department of Clinical Medicine, Faculty of Veterinary Medicine and Zootechny, University of São Paulo, Av. Prof. Orlando Marques de Paiva 87, 05508-900 São Paulo, SP, Brasil. (2) Veterinary Teaching Hospital, Faculty of Veterinary Medicine and Zootechny, University of São Paulo, São Paulo, SP, Brasil.

Correspondence to: Mitika K. Hagiwara, mkhagiwara @ usp.br 
The lack of data regarding Toxoplasma infection in the cat population of São Paulo was the major factor for the decision to conduct the present study. The aim was to evaluate the occurrence of Toxoplasma gondii infection in house cats using the indirect immunofluorescence assay. Feeding habits and housing were considered in an attempt to study some epidemiological factors involved in the rate of infection.

\section{MATERIALS AND METHODS}

\section{Materials}

A total of 248 serum samples obtained from cats seen at the Veterinary Teaching Hospital, University of São Paulo from February 1996 to January 1997 were tested. Serum samples were stored at $-20{ }^{\circ} \mathrm{C}$ up to the immunofluorescence assay (IFA) and divided into groups according to animal sex, age, access to the external environment and diet.

\section{Methods}

IFA was perfomed using the commercially available Toxoplasma gondii freeze-dried antigen (Imunotoxo ${ }^{\circledR}$, BIOLAB).

The total feline gammaglobulin conjugate was prepared in the Applied Immunology Laboratory of the Preventive Veterinary Medicine and Public Health Department of the Veterinary Medicine School, University of São Paulo. The fluorescent conjugate was titrated according to the method described by CAMARGO, $1974^{4}$ and the titer was 40 . The IFA was performed in the Clinical Analysis Laboratory of the Department of Internal Medicine of the Veterinary Medicine School, University of São Paulo, according to CAMARGO, 1974 ${ }^{4}$ Negative and positive controls were obtained by infecting young kittens with Toxoplasma gondii (cepa RH). Seroconversion was observed by indirect hemagglutination.

Statistical analysis was performed using the double proportion test ${ }^{2}$, with an estimated alpha value of $5 \%$.

\section{RESULTS}

Of the 248 studied animals, $44(17.7 \%)$ were positive for Toxoplasma antibodies by the IFA. The highest frequency $(41.7 \%)$ of reagents was found in cats aged 12 years or older (Table 1). Significant differences $(p<0.05)$ were observed between the oldest and youngest animals, i.e., the reaction rate was higher in the group above six years of age, whereas the 12-year old+ group showed a significantly higher number of positive animals when compared to the total sum of all groups up to 12 years of age $(\mathrm{p}<0.05)$.

Table 1 shows the antibody titers of all animals with positive serological reaction to Toxoplasma gondii. The most frequently detected titer was 64, present in $14(31.8 \%)$ animals. The highest titers were detected in animals up to five years of age.

As to gender, 107 (43.2\%) samples were obtained from females, and $20.6 \%$ were positive. A total of $141(56.8 \%)$ samples were obtained from males, and $15.6 \%$ were positive. There was no statistically significant difference in the number of positive males and females ( $p>0.05)$.

Concerning the habits as informed by the owners, most cats, although domiciled, had free access to the outdoor environment (Table 2). A significant difference in positivity was found between animals with or without free access to the outdoors $(\mathrm{p}<0.05)$.

The diet of the animals was also considered, since it might influence the number of animals reactive to Toxoplasma. The results are shown in Table 3. The analysis showed a significant difference between animals receiving commercial cat food and raw meat or home made food or only commercial cat food $(\mathrm{p}<0.05)$ There was no significant difference between cats receiving commercial food or home-made diets with cooked meat, rice, and liver or sardines ( $>>0.05)$.

As can be seen in Table 4, among animals receiving some form of "meat" (raw or "home diet") there was no significant difference between

TABLE 1

Distribution, frequency and titers of Toxoplasma antibodies in cats according to age group. São Paulo, 1997

\begin{tabular}{|c|c|c|c|c|c|c|c|c|}
\hline \multirow[b]{2}{*}{ Age Group } & \multirow[b]{2}{*}{$\mathrm{N}$} & \multicolumn{6}{|c|}{ Toxoplasma antibody titers } & \multirow[b]{2}{*}{$\begin{array}{l}\text { Total number of } \\
\text { positive samples }\end{array}$} \\
\hline & & NR & 16 & 64 & 256 & 1024 & 4096 & \\
\hline$<6 \mathrm{~m}$ & 24 & $23(95.8 \%)$ & - & - & - & $01(4.2 \%)$ & - & $01(4.2 \%)$ \\
\hline $7-12 m$ & 36 & $33(91.7 \%)$ & $02(5.5 \%)$ & - & - & - & $01(2.8 \%)$ & $03(8.3 \%)$ \\
\hline $1-3 \mathrm{y}$ & 84 & $71(84.5 \%)$ & $04(4.7 \%)$ & $05(6.0 \%)$ & $02(2.4 \%)$ & $01(1.2 \%)$ & $01(1.2 \%)$ & $13(15.5 \%)$ \\
\hline $4-5 y$ & 33 & $27(81.9 \%)$ & $01(3.0 \%)$ & $01(3.0 \%)$ & $02(6.1 \%)$ & $01(3.0 \%)$ & $01(3.0 \%)$ & $06(18.1 \%)$ \\
\hline $6-8 \mathrm{y}$ & 31 & $23(74.2 \%)$ & $01(3.2 \%)$ & $03(9.7 \%)$ & $04(12.9 \%)$ & - & - & $08(25.8 \%)$ \\
\hline $9-12 \mathrm{y}$ & 28 & $20(71.4 \%)$ & $02(7.2 \%)$ & $03(10.7 \%)$ & $03(10.7 \%)$ & - & - & $08(28.6 \%)$ \\
\hline$>12 \mathrm{y}$ & 12 & $07(58.3 \%)$ & $02(16.7 \%)$ & $02(16.7 \%)$ & $01(8.3 \%)$ & - & - & $05(41.7 \%)$ \\
\hline Total & 248 & $204(82.3 \%)$ & $12(4.8 \%)$ & $14(5.7 \%)$ & $12(4.8 \%)$ & $03(1.2 \%)$ & $03(1.2 \%)$ & $44(17.7 \%)$ \\
\hline
\end{tabular}

$\mathrm{NR}=$ non-reactive

$\mathrm{m}=$ months

$\mathrm{y}=$ years 


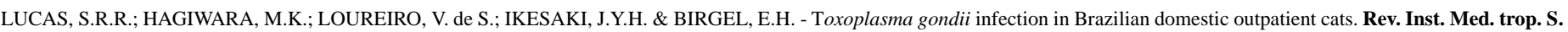
Paulo, 41 (4): 221-224, 1999.

TABLE 2

Distribution and frequency of Toxoplasma antibodies in cats, with or without free access to the outdoor environment. São Paulo, 1997

\begin{tabular}{lccc}
\hline \multicolumn{4}{c}{ Toxoplasma antibodies } \\
\hline Cats & Positive & Negative & Total \\
\hline Outdoor & $29(23.6 \%)$ & $94(76.4 \%)$ & $123(100.0 \%)$ \\
Indoor & $10(11.8 \%)$ & $75(88.2 \%)$ & $85(100.0 \%)$ \\
\hline Total & $39(18.8 \%)$ & $169(81.2 \%)$ & $208(100.0 \%)$ \\
\hline
\end{tabular}

TABLE 3

Distribution and frequency of Toxoplasma antibodies in cats according to type of diet. São Paulo, 1997

\begin{tabular}{llll}
\hline \multicolumn{4}{c}{ Toxoplasma antibodies } \\
\hline Diet Type & Positive & Negative & Total \\
\hline $\begin{array}{l}\text { Comm. } \\
\text { Cat food }\end{array}$ & $10(11.1 \%)$ & $80(88.9 \%)$ & $90(100.0 \%)$ \\
\hline $\begin{array}{l}\text { Home-made } \\
\text { cooked food }\end{array}$ & $02(10.0 \%)$ & $18(90.0 \%)$ & $20(100.0 \%)$ \\
\hline $\begin{array}{l}\text { Comm. food, } \\
\text { raw meat / } \\
\text { home-made food }\end{array}$ & $32(24.1 \%)$ & $101(75.9 \%)$ & $133(100.0 \%)$ \\
\hline \begin{tabular}{l} 
Total \\
\hline
\end{tabular} & $44(18.1 \%)$ & $199(81.9 \%)$ & $243(100.0 \%)$ \\
\hline
\end{tabular}

those with or without free access to the external environment ( $p>0.05)$. Comparison of cats receiving commercial diets and meat and cats on commercial diets only showed no significant differences ( $p>0.05)$. Among cats fed only commercial diets, $19.5 \%$ of the animals with access to the outdoors were positive, and none of the exclusively indoor cats showed a positive serologic response.

\section{DISCUSSION}

Toxoplasma antibodies were detected in $17.7 \%$ of the 248 serum samples tested by IFA.This frequency strongly differed from those described by SOGORB et al. in 1972, who found $45.0 \%$ of positive cats using the Sabin-Feldman reaction test. LARSSON et al., in 1982, detected $40.8 \%$ of positive cats using the Sabin-Feldman reaction test. SANTOS et al., in 1983, analyzed 100 serum samples using the passive hemagglutination test and detected $59.0 \%$ positive results. SALATA et $a l$., in 1985, tested 9 serum samples obtained from cats in Botucatu, SP, using IFA. All samples were found to be negative.

No difference in the rate of reactive animals was observed between males and females (Table 2), suggesting that they are equally susceptible to Toxoplasma infection. This agrees with previous results obtained by LARSSON et al., 1982, and SOGORB et al., 1972.

Analysis of positive animals according to age showed that few animals were infected in the early stages of life, and that the rate of infection increased with age, as shown in Table 1. Older animals had a higher prevalence of Toxoplasma infection, in agreement with data
TABLE 4

Distribution and frequency of Toxoplasma antibodies in cats, according to type of diet and possibility of free access to the outdoor environment. São Paulo, 1997

\begin{tabular}{lccc}
\hline \multicolumn{4}{l}{ Toxoplasma antibodies } \\
\hline Diet/Behavior & Positive & Negative & Total \\
\hline $\begin{array}{l}\text { Only comm. } \\
\text { food or home } \\
\text { cooked diet/indoor }\end{array}$ & $01(2.2 \%)$ & $45(97.8 \%)$ & $46(100.0 \%)$ \\
\hline $\begin{array}{l}\text { Comm. food, } \\
\text { raw meat, home } \\
\text { diet/indoor }\end{array}$ & $09(19.1 \%)$ & $38(80.9 \%)$ & $47(100.0 \%)$ \\
\hline $\begin{array}{l}\text { Only comm. } \\
\text { food or home } \\
\text { cooked diet/outdoor }\end{array}$ & $09(18.4 \%)$ & $40(81.6 \%)$ & $49(100.0 \%)$ \\
\hline $\begin{array}{l}\text { Comm.food, } \\
\text { raw meat, home } \\
\text { diet/outdoor }\end{array}$ & $20(30.3 \%)$ & $46(69.7 \%)$ & $66(100.0 \%)$ \\
\hline Total & $39(18.7 \%)$ & $169(81.3 \%)$ & $208(100.0 \%)$ \\
\hline
\end{tabular}

reported by FRENKEL et al., 1987, SOGORB et al., 1972, and LARSSON et al., 1982, although SOGORB and LARSSON divided the animals into only two groups, i.e. young and adult cats. This finding can be explained by the risk of exposure of older animals to the infective stages of the parasite through life, since the infection persists for the whole life of the host.

The most frequently found antibody titer was 64 (Table 1). The highest titers were detected in cats up to 5 years of age, and could be attributed to more recent infection in younger animals. Lower titers, detected in older animals, may suggest latent infection. Cats, in general, develop Toxoplasma antibodies more slowly and do not achieve titers described in humans and other mammalian species ${ }^{5}$. This impairs the interpretation of a single serological test in cats.

Diet and access to the outdoor environment are important factors when considering the lower prevalence of toxoplasmosis detected in the present study, compared to the findings of previous studies in São Paulo. Domiciled cats with free access to the outdoor environment have the opportunity to hunt for small preys, thus becoming more susceptible to infection by Toxoplasma gondii than cats exclusively kept indoors. Statistical analysis showed a significant difference between animals with and without access to the outdoor environment, confirming that nonconfined cats are at higher risk of being exposed to Toxoplasma. Many cats included in this study live in apartments with no chance of reaching the outdoors and consequently with a lower possibility of infection.

Another factor to be considered is the marked change in diets in the last ten years, with the introduction of commercial cat foods on the Brazilian market. Temperatures above $100^{\circ} \mathrm{C}$ used during food processing make tissue cysts nonviable. Toxoplasma in meat is killed by heating the meat throughout to $66^{\circ} \mathrm{C}^{7,10}$. In this study, only $8.1 \%$ of the cats were fed home-cooked meals (cooked meat, rice, liver or sardines) and more than $90 \%$ were fed commercial pet foods, although many owners still add raw meat to the diet. 
A significant difference in the prevalence of infection was observed between animals receiving commercial cat food and fed raw meat $(p<0.05)$ and between those receiving commercial cat food with the addition of raw meat and those fed only commercial food $(\mathrm{p}<0.05)$. These data suggest that diet greatly influenced the incidence of infection. As to the influence of outdoor access on the occurrence of infection, there was no statistically significant difference between cats receiving cat food and meat with free access to the outdoors and those fed only cat food with access to the outdoors. Similar findings resulted from the comparison of animals fed meat but kept strictly domiciled and those fed commercial cat food but with free access to the outdoors. Diets containing raw meat and access to the outdoor environment are equally important factors in the occurrence of Toxoplasma gondii infection in cats.

We observed that in the absence of those factors, 39 cats $(100 \%)$ were negative with respect to $T$. gondii antibodies. This result was expected, since the way these animals were kept by their owners practically eliminated any risk of exposure to the infection.

The results obtained in this study lead us to conclude that diets and free access to the outdoor environment were equally important as predisposing factors to the risk of infection. Thus, keeping cats indoors and feeding them commercial diets may contribute to the reduction in the prevalence of Toxoplasma infection in the urban cat population.

\section{RESUMO}

\section{Infeçcão por Toxoplasma gondii em gatos domésticos atendidos em um Hospital Veterinário em São Paulo}

A ocorrência de anticorpos antitoxoplasma em gatos domésticos, atendidos no Hospital Veterinário da Faculdade de Medicina Veterinária e Zootecnia da Universidade de São Paulo, foi avaliada pela técnica de imunofluorescência indireta.

Foram analisadas 248 amostras de soro sangüíneo de gatos, machos ou fêmeas, portadores de diversas condições mórbidas. Desse total, 17,7\% foram reagentes, sendo 64 o título encontrado na maioria dos animais.

A freqüência de anticorpos antitoxoplasma foi significativamente maior nos gatos mais velhos, naqueles alimentados de alguma forma com carne crua e naqueles com livre acesso à rua. Não houve diferença significante na freqüência de machos e fêmeas reagentes. Os resultados demonstram que o tipo de alimentação e a manutenção do animal em ambiente exclusivamente domiciliar ou com livre acesso à rua são fatores de risco igualmente importantes na ocorrência da infecção toxoplásmica em gatos.

\section{ACKNOWLEDGEMENTS}

The authors wish to express their appreciation to Dr. Leonardo José Richtzenhain, Applied Immunology Laboratory, Department of Veterinary Preventive Medicine and Public Health, Faculty of Veterinary Medicine, University of São Paulo, for his kind help with the IFA and to Irina Zablith for her assistance in translating the text into English.

\section{REFERENCES}

1. AMATO NETO, V.; CAMPOS, R.; BARUZZI, R.G. \& DUARTE, M.I.S. - Toxoplasmose. São Paulo, Sarvier, 1982.

2. BERQUÓ, E.S.; SOUZA, J.M.P. \& GOTLIEB, S.B. - Bioestatística. São Paulo, Ed. Pedagógica e Universitária, 1981.

3. BOWIE, W.R.; KING, A.S.; WERKER, D.H. et al. - Outbreak of toxoplasmosis associated with municipal drinking water. Lancet, 350: 173-177, 1997.

4. CAMARGO, M.E. - Introdução às técnicas de imunofluorescência. Rev. bras. Pat. clín., 10: $57-71,87-107,143-171,1974$

5. DUBEY, J.P. \& FRENKEL, J.K. - Cyst-induced toxoplasmosis in cats. J. Protozool., 19: $155-177,1972$

6. DUBEY, J.P. \& BEATTIE, C.P. - Toxoplasmosis of animals and man. Boca Raton, CRC Press, 1988.

7. DUBEY, J.P. - Toxoplasmosis. J. Amer. vet. med. Ass., 205: 1593-1598, 1994.

8. DUBEY, J.P. - Strategies to reduce transmission of Toxoplasma gondii to animals and humans. Vet. Parasit., 64: 65-70, 1996.

9. FRENKEL, J.K.; DUBEY, J.P. \& MILLER, N.L. - Toxoplasma gondii in cats: fecal stages identified as coccidian oocysts. Science, 167: 893-896, 1970.

10. FRENKEL, J.K. \& DUBEY, J.P. - Toxoplasmosis and its prevention in cats and man. J. infect. Dis., 126: 664-673, 1972.

11. FRENKEL, J.K. - Toxoplasma in and around us. Bioscience, 23: 343-352, 1973.

12. FRENKEL, J.K.; NELSON, B.M. \& ARIAS-STELLA, J. - Immunosuppression and toxoplasmic encephalitis: clinical and experimental aspects. Hum. Path., 6: 97-111, 1975 .

13. FRENKEL, J.K.; KIER, A.B.; WAGNER, J.E. \& HOLZWORTH, J. - Protozoan diseases. In: HOLZWORTH, J. Diseases of the cat. Medicine \& Surgery. Philadelphia, W.B.Saunders, 1987. v.1, p.359.

14. LAPPIN, M.R. - Feline toxoplasmosis: interpretation of diagnostic test results. Semin. vet. Med. Surg., 11: 154-160, 1996.

15. LARSSON, C.E.; JAMRA, L.M.F. \& RIBEIRO, M.F. - Prevalência de toxoplasmose felina determinada pela reação de Sabin-Feldman, em São Paulo. In: CONFERÊNCIA ANUAL DA SOCIEDADE PAULISTA DE MEDICINA VETERINÁRIA, 37, Pirassununga, 1982.

16. LUFT, B.J.; BROOKS, R.G.; CONLEY, F.K.; McCABE, R.E. \& REMINGTON, J.S. Toxoplasmic encephalitis in patients with acquired immune deficiency syndrome. J. Amer. med. Ass., 252: 913-917, 1984.

17. McCABE, R. \& REMINGTON, J.S. - Toxoplasmosis: the time has come. New Engl. J. Med., 318: 313-315, 1988.

18. SALATA, E.; YOSHIDA, E.L.A.; PEREIRA, E.A. \& CORREA, F.M.A - Toxoplasmose em animais silvestres e domésticos da região de Botucatu, Estado de São Paulo, Brasil. Rev. Inst. Med. trop. S. Paulo, 27: 20-22, 1985.

19. SANTOS, S.M.; AMARAL, V.; REBOUÇAS, M.M. \& DRUMOND, L.S. - Anticorpos antitoxoplasma detectados por hemaglutinação indireta em soros de gatos domésticos provenientes da capital do estado de São Paulo, Brasil. Biológico, 49: 163-165, 1983.

20. SOGORB, F.; JAMRA, L.F.; GUIMARÃES, E.C. \& DEANE, M.P. - Toxoplasmose espontânea em animais domésticos e silvestres, em São Paulo. Rev. Inst. Med. trop. S. Paulo, 14: 314-320, 1972.

Received: 17 March 1998

Accepted: 20 July 1999 